\title{
Background for forming a unified methodological approach to risk assessment of new transport construction projects
}

\author{
Irina Solskaya*, Svetlana Khaletskaya, Oksana Rabushenko, and Sofia Golovan \\ Irkutsk State Transport University, Department of strategic and risk management, 664074 Irkutsk, \\ Russia
}

\begin{abstract}
In the most general case, the assessment of the risks of investment projects is carried out on the basis of a single standard methodological approach, sufficiently adapted to a large number of industry structures. However, new projects implemented in order to expand and radically modify the infrastructure of railway transport in the Russian Federation require clarification of the principles and provisions of existing approaches for their reasonable implementation. The reason for this lies in the sectoral features of the projects: the return on investment is longer than in other sectors; the social importance of new infrastructure facilities; attraction of budgetary resources to finance new transport construction projects. The article discusses the main prerequisites for the formation of a methodological approach to the analysis and assessment of the risks of construction of infrastructure facilities of railway transport. The author's approach to assessing the risks of projects for the construction of infrastructure facilities is proposed from the standpoint of their relationship with the characteristics of project stakeholders, which determines the directions of risk analysis at the current stage of project implementation and the consequences of the previous stages.
\end{abstract}

\section{Introduction}

The analysis of the results of the implementation of new construction projects in railway transport, carried out in the process of research, showed that the use of project financing models for assessing the risks of new construction projects in order to expand and develop the capacity of the railway transport infrastructure requires modification and development [1]. in relation to routes providing transportation on the eastern range, and oriented to freight transportation of raw materials extracted in Eastern Siberia and the Republic of Sakha, and transported in one direction [2]. The study of approaches to risk management in infrastructure projects, especially with budgetary funding, has received wide coverage in the scientific literature. Risk transfer in such a case may not always contribute to effective management due to problems with the main agent. Thus, some authors highlight such parameters as competition, monitoring and incentives for transferring risks in a relationship with the main agent. The results show that competition determines the ability of the private

${ }^{*}$ Corresponding author: irina_solskaya_@mail.ru 
sector to bear risks, monitoring reduces information asymmetries ex post, and incentives ensure effective risk management. [3]. There are also studies showing that public-private partnerships in infrastructure projects increase the efficiency of infrastructure modernization. The authors used cluster analysis, which makes it possible to reduce the arbitrariness and subjectivity of the analysis of projects involved in the analysis of the research topic [4].

Public-private partnership (PPP) is accepted all over the world for the development of public infrastructure. While global experience has shown that PPPs can provide various benefits to government, to fully obtain them, several critical aspects of a PPP project need to be managed, including the timing of the concession. The authors from Italy presented a methodology for calculating the concession period as the best moment in time, which creates a "win-win" solution for both the concessionaire and the government and allows fair sharing of risks between the two parties. In other words, the concession period can satisfy the individual and the state, guaranteeing both parties a minimum profit and, at the same time, fairly distribute the risks between the parties. To account for the uncertainty that affects PPP projects, Monte Carlo simulations were used [5].

At the same time, three additions have been made by other authors to further investigate the effects of the structure of the concession period: when the toll price is determined by a private firm; in case of repeated negotiations and in the presence of a policy of state support. Based on the results of the model, conclusions are drawn regarding the development of contracts for the construction of roads within various structures of concession periods [6].

\section{Materials and methods}

Analysis of the features of new construction projects associated with the development of railway transport infrastructure [7] allowed the main stakeholders and the reasons for the riskiness of the implementation of new railway construction projects:

1. The main stakeholder in most cases is the state. This is due to the fact that infrastructure projects are associated with a large volume of capital costs, a limited private investment market and a low, in relation to the average market, level of income potential.

2. Another category of stakeholders - consignors - due to the peculiarities of the development of the production potential of the eastern territories of the Russian Federation, is quite small, in addition, it is focused on existing transport services and directions of transportation.

3. Infrastructure projects in railway transport, involving the construction of new tracks or networks, are aimed at expanding the existing carrying capacity of operating the transport network. They, as a rule, in addition to the expansion of the railway infrastructure itself, which, in fact, is the object of project construction, can include the development of infrastructure for other types of transport (parking lots, roadways, terminal facilities, etc.), as well as the creation of conditions for servicing the increasing freight turnover (expansion platforms, modernization of freight stations, expansion of operational depots, construction of non-public access roads, modernization of supporting systems to ensure traffic safety, new rolling stock, dismantling of redundant branches, improving the system of corporate transport services, etc.

4. The implementation of new construction projects is possible through the mechanism of public-private partnership, however, its role, fixed by the pre-project stages of the project, is usually limited to solving the problem of underfunding, which stimulates private investors - stakeholders - to invest in the early stages of design and construction. In practice, the mechanism of state- private partnership in conditions of refusal of a private investor from its obligations has increased the risks of its completion. 
5. Due to the monopoly nature of railway infrastructure services, the state strives to maintain an affordable level of railway tariffs, therefore the lack of government support can significantly affect the risk of reducing the financial stability of the project. In addition, the solution of socially significant tasks within the framework of social policy presupposes the implementation of state investments. In conditions of limited budgetary resources, the problem of underfunding inevitably arises, leading to the impossibility of a timely transition to the operation stage.

6. Consideration of project risks is necessary, therefore, to ensure the effectiveness of budgetary expenditures. The ability to choose from many options for the implementation of investment projects requires adequate criteria for assessing and ranking projects according to the criterion of riskiness, followed by the choice of the best option, taking into account the risks of the project at all stages of its implementation [8].

\section{Results and Discussion}

The fundamental task of developing a new methodological approach to identifying and localizing the risks of new transport construction projects is to establish the relationship between the stage of project implementation, object and subject and the feasibility of subsequent stages of construction and operation of new infrastructure facilities (Table 1).

Table 1. Relationship between the stage of a new transport construction project and the risks of its implementation.

\begin{tabular}{|c|c|c|c|}
\hline $\begin{array}{l}\text { Standard stage } \\
\text { of project } \\
\text { activities }\end{array}$ & $\begin{array}{l}\text { The content of the } \\
\text { project activities }\end{array}$ & $\begin{array}{l}\text { Risks of } \\
\text { subsequent } \\
\text { stages * }\end{array}$ & $\begin{array}{l}\text { Object and subject of analysis and risk } \\
\text { assessment of subsequent stages }\end{array}$ \\
\hline \multirow[t]{2}{*}{ Initialization } & $\begin{array}{l}\text { - goal setting, } \\
\text { limitations and } \\
\text { priorities of the } \\
\text { project; } \\
\text { - options for the spatial } \\
\text { implementation of the } \\
\text { project }\end{array}$ & P3 & $\begin{array}{l}\text { Stakeholders - market position, } \\
\text { Stakeholders are alternative ways of providing } \\
\text { transport services, Alternative transport } \\
\text { infrastructure - availability and condition }\end{array}$ \\
\hline & $\begin{array}{l}\text { development of the } \\
\text { project assignment and } \\
\text { strategic planning of } \\
\text { the project }\end{array}$ & $\mathrm{P} 2$ & $\begin{array}{l}\text { Spatial polygon realization - development and } \\
\text { use, Project executors - availability and } \\
\text { condition of production facilities, Performers } \\
\text { of the project - the level of technology of the } \\
\text { performer of the project, Project executors - } \\
\text { estimated project costs, Project executors - } \\
\text { organization of design work }\end{array}$ \\
\hline \multirow[t]{5}{*}{ Design } & $\begin{array}{l}\text { identifying the } \\
\text { interests of the main } \\
\text { stakeholders }\end{array}$ & P4 & $\begin{array}{l}\text { Stakeholders - the potential for economic } \\
\text { development, Strategy for the development of } \\
\text { the economy of the state and territories - } \\
\text { macro and microeconomic factors of the } \\
\text { project }\end{array}$ \\
\hline & $\begin{array}{l}\text { determination of the } \\
\text { amount of project } \\
\text { financing }\end{array}$ & P1 & $\begin{array}{l}\text { Stakeholders - planned costs at the stage of } \\
\text { project implementation }\end{array}$ \\
\hline & $\begin{array}{l}\text { determination of } \\
\text { stages, deadlines and } \\
\text { milestones of the } \\
\text { project }\end{array}$ & P3 & $\begin{array}{l}\text { Project executors - market position, } \\
\text { Competitive environment - alternative ways of } \\
\text { project implementation, Spatial polygon } \\
\text { realization - the presence of a supporting } \\
\text { infrastructure }\end{array}$ \\
\hline & $\begin{array}{l}\text { an estimate of the total } \\
\text { resources required to } \\
\text { complete the project }\end{array}$ & P4 & $\begin{array}{l}\text { Stakeholders - resource base, Stakeholder- } \\
\text { market capitalization, Stakeholder -investment } \\
\text { potential }\end{array}$ \\
\hline & object construction & P1 & $\begin{array}{l}\text { Project executors - current cost, Performers of } \\
\text { the project - the boundaries of the permissible } \\
\text { deviation from the estimated cost }\end{array}$ \\
\hline
\end{tabular}


Table 1. Continued.

\begin{tabular}{|l|l|l|l|}
\hline Implementation & $\begin{array}{l}\text { solution of emerging } \\
\text { technical and } \\
\text { technological problems }\end{array}$ & P2 & $\begin{array}{l}\text { Spatial polygon realization - transformation } \\
\text { during construction, Project executors - the } \\
\text { implementation process, Executors of the } \\
\text { project - the state of capital assets, Project } \\
\text { executors - technological level of project } \\
\text { activity }\end{array}$ \\
\cline { 2 - 4 } & $\begin{array}{l}\text { informing participants } \\
\text { about the results of } \\
\text { implementation }\end{array}$ & P6 & $\begin{array}{l}\text { Strategy for the development of the economy } \\
\text { of the state and territories - forecast } \\
\text { parameters of stock instruments }\end{array}$ \\
\cline { 2 - 5 } & managing plan changes & P2 & $\begin{array}{l}\text { Spatial implementation polygon - refined } \\
\text { implementation polygon, Project } \\
\text { implementers - modified implementation } \\
\text { process, New construction object - } \\
\text { clarification of the state of newly } \\
\text { commissioned infrastructure facilities, Project } \\
\text { executors - technological level of design work }\end{array}$ \\
\hline $\begin{array}{l}\text { Completion of } \\
\text { design work. } \\
\text { Exploitation }\end{array}$ & $\begin{array}{l}\text { customer satisfaction } \\
\text { score } \\
\text { operation }\end{array}$ & P5 & $\begin{array}{l}\text { New construction object - planned financial } \\
\text { results of operation }\end{array}$ \\
\cline { 2 - 4 } & $\begin{array}{l}\text { Stakeholders - the production potential of } \\
\text { shippers, The strategy for the development of } \\
\text { the economy of the state and territories is a } \\
\text { strategy for the development of material } \\
\text { flows, Macro and meso-economic situation - } \\
\text { alternative infrastructure facilities and } \\
\text { services }\end{array}$ \\
\hline
\end{tabular}

${ }^{*}$ Here:

P1 - contractual risks - change or incomplete amount of project financing;

P2 - technical risks - conditions for the implementation and subsequent operation of the project - risks of man-made accidents;

P3 - risks of competitiveness - exposure of the project to market risks - changes in the timing of the project, including due to a possible change in the macroeconomic situation;

P4 - legal risks of the project structure - distribution of risks between project stakeholders (for publicprivate partnership projects, risks are borne by both the state and private investors);

P5 - operational risks of the stakeholder - the initiator of the investment project - changes in the timing of the implementation of projects for the extraction of minerals, non-presentation by the shippers of the declared volumes of cargo;

P6 - financial risks - capitalization of assets, changes in the market value of the investment portfolio.

\section{Conclusion}

Identification of objects of assessment of potential sources of risks in accordance with each of the standard stages of project implementation [9] allows you to determine at the stage of pre-project research methods of risk management from the standpoint not only of the feasibility of the project, but also from the point of view of solving urgent socio-economic problems of the state, which is the main stack holder of projects development of transport infrastructure.

\section{Acknowledgements}

The article was funded by the R\&D project No. 121042700206-9 "Evaluation of the effectiveness of services provided (work performed) based on rating indicators" in accordance with the government task No. 109-00004-21-00. 


\section{References}

1. A. V. Ivanovsky, I. Yu. Solskaya, O. A. Rabushenko, Modern technologies. System analysis. Modeling, 4(48) (2015)

2. I. Yu. Solskaya, A. V. Ivanovsky, Modern technologies. System analysis. Modeling, 2(50) (2016)

3. A. Shrestha, T. K. Chan, A. A. Aibinu, C. Chen, Utilities policy, 48, 132 (2017)

4. C. Cui, Y. Liu, A. Hope, J. Wang, International Journal of Project Management, 36(5), 773 (2018)

5. N. Carbonara, N. Costantino, R. Pellegrino, International journal of project management, 32(7), 1223 (2014)

6. Y. Zhang, Z. Feng, S. Zhang, Transportation research part A: policy and practice, 107, 106 (2018)

7. N. V. Kapustina, E. A. Stupnikova, O. A. Olenina, M. M. Gerasimov, State and municipal administration. Scholarly Notes, 1 (2020)

8. J. E. Stiglitz, A. Sen, J. P. Fitoussi, Report by the commission on the measurement of economic performance and social progress (2009)

9. P. V. Kurenkov, T. A. Zaitsev, Logistics and supply chain management, 6, 45 (2015) 